\title{
Performance Evaluation of Monocrystalline and Polycrystalline Silicon Solar Photovoltaic Modules Under Low and High Irradiance Conditions in Kumasi, Ghana
}

\author{
G. Takyi*, A. S. Adunyah, A. Agyei-Agyemang \\ Kwame Nkrumah University of Science and Technology, Kumasi, GHANA.
}

\begin{abstract}
One of the biggest drawbacks of photovoltaic (PV) for many applications is the uncertainty in the energy output due to losses attributed to efficiency loss at low irradiance levels. In this study, the electrical performance of asreceived monocrystalline silicon (mono-c-Si) and polycrystalline silicon (poly-c-Si) PV modules were evaluated at high and low irradiance conditions in Kumasi, Ghana using I-V Tracer. The low irradiance level of $200 W / \mathrm{m}^{2}$ was achieved by covering the surface of the $P V$ modules with a calibrated mesh screen. Maximum output power $\left(P_{\max }\right)$ of $87.9 \mathrm{~W}$ and $136.7 \mathrm{~W}$ were recorded for the mono-c-Si and poly-c-Si modules at high irradiance respectively. The corresponding average values at low irradiance were $8.29 \mathrm{~W}$ and $12.13 \mathrm{~W}$ representing percentage reductions of $90.57 \%$ and $91.60 \%$ respectively for the two technologies. These results indicate that when irradiance drops to 200 $\mathrm{W} / \mathrm{m}^{2}$ and below, the $\mathrm{PV}$ modules generate around only $10 \%$ of their nominal output power. This has implications for the number of modules that are required for installation in areas that experience many hours of low irradiance. Efficiency reductions of $64.4 \%$ and $59.01 \%$ for the mono-c-Si and poly-c-Si modules respectively at low irradiance is reported. The results also indicate that the mono-c-Si is affected more by light induced degradation effect than the poly-c-Si module after a few hours of exposure to the natural light. The novelty of this work is that knowledge of the performance at low irradiance will enable designers determine the number of modules required during the sizing of PV plants.
\end{abstract}

Keywords: solar energy, photovoltaic, performance, efficiency, light induced degradation

\section{INTRODUCTION}

PV module performance is typically rated using a single operating point at standard test conditions (STC) as per the IEC 61215 standard, consisting of a $1000 \mathrm{~W} / \mathrm{m}^{2}$ irradiance, $25^{\circ} \mathrm{C}$ module temperature and AM1.5 (Air Mass of 1.5) spectrum [1]. These ratings assist the PV designer or investor to predict the annual energy output of the module. However, these conditions are rarely achieved in actual installations. Due to variations of the sun's position each day and the apparent motion of the sun throughout the year, the total irradiance received at a particular site varies throughout the year [2]. Specifically, for outdoor PV applications, insolation levels are much different from those of STC which results in variation in PV system efficiency [3]. Further, due to parasitic resistances, the efficiency of a PV module is not constant as the intensity of the solar irradiance changes [4]. One of the biggest drawbacks of solar $\mathrm{PV}$ for many applications is the uncertainty in the

\footnotetext{
* Corresponding author (Tel: +233 203802 911)

Email addresses: gtakyi.soe@knust.edu.gh (G. Takyi), adwoasadunya@gmail.com (A. S. Adunyah), tonyagyemang@yahoo.com (A. Agyei-Agyemang)
}

energy output which is due to losses attributed to inherent efficiency loss at low irradiance levels among other environmental factors [3]. At high irradiance (for example $1000 \mathrm{~W} / \mathrm{m}^{2}$ ) and low temperature (around $25^{\circ} \mathrm{C}$ ), the modules are expected to produce very close to the manufacturer's nameplate rating. It is, however, not certain how much energy could be extracted from the PV modules as the irradiance drops as low as $200 \mathrm{~W} / \mathrm{m}^{2}$. Different solar PV technologies also respond differently to solar irradiation intensity.

Several researchers have sought to investigate the performance of I-V parameters of PV modules with changing irradiance and temperature. Chegaar, et al. [5] investigated the effect of illumination intensity on solar cells parameters on single polycrystalline silicon solar cells under room temperature ranging from $20-25^{\circ} \mathrm{C}$ (average of $23^{\circ} \mathrm{C}$ ). The solar cell was utilized for indoor applications. The intensity range used for the experiment was $160 \mathrm{~W} / \mathrm{m}^{2}-1000 \mathrm{~W} / \mathrm{m}^{2}$. The results showed a linear increase in the short circuit current $\left(I_{s c}\right)$ and maximum power with irradiation. The open circuit voltage $\left(V_{o c}\right)$ however, increased logarithmically. The fill factor increased slightly at low irradiance $\left(\mathrm{I}<500 \mathrm{~W} / \mathrm{m}^{2}\right)$ 
and then decreased at higher intensities of irradiation $\left(\mathrm{I}>500 \mathrm{~W} / \mathrm{m}^{2}\right)$. It was further observed and concluded that the conversion efficiency increases logarithmically for $\mathrm{I}<400 \mathrm{~W} / \mathrm{m}^{2}$ but with irradiance above $400 \mathrm{~W} / \mathrm{m}^{2}$ the efficiency was almost invariable. The single polycrystalline silicon solar cells were not exposed to outdoor conditions where the impact of irradiance on the solar cells could be a little more severe. Musanga et al. [6] addressed the aforementioned limitation of Chegaar et al.'s experiment by investigating the effect of irradiance and temperature on the performance of monocrystalline silicon solar module under outdoor conditions in Kakamega, Kenya. That notwithstanding, Musanga et al.'s investigation yielded similar results as Chegaar et al's in 2013. From their investigation, it was concluded that Isc of the module increased significantly with increasing irradiance whilst the Voc was least affected by increasing or decreasing irradiance. Further, both fill factor and efficiency showed a similar trend with irradiance; increasing slightly and then reducing. Mandadapu et al. [7] examined the effect of irradiance on the electrical performance of a PV module using MATLAB. Irradiance was varied for $400 \mathrm{~W} / \mathrm{m}^{2}, 600 \mathrm{~W} / \mathrm{m}^{2}$ and 800 $\mathrm{W} / \mathrm{m}^{2}$. It was determined that the efficiency of the PV module increased with increasing irradiance. $I_{s c}$ and $V_{o c}$ also increased.

Although Mandadapu's research provides an overview of how the polycrystalline modules behave under fluctuating irradiance, the lowest irradiance of $400 \mathrm{~W} / \mathrm{m}^{2}$ was not conclusive enough. What if the irradiance level falls below $400 \mathrm{~W} / \mathrm{m}^{2}$ ? In the tropical regions, Bashir et al.[8] compared the performance measurements of PV modules during winter months in Taxila, Pakistan. Three commercially available PV modules were used. This included the monocrystalline, polycrystalline and single junction amorphous silicon modules. The effect of solar irradiance on power output, module efficiency and performance ratio were investigated. It was determined that monocrystalline and polycrystalline modules performed better in high irradiance condition whereas with a decrease in irradiance, the performance decreased as well. Rosyid [9] indicated that this was because as solar irradiance increases, other variables such as temperature, voltage and current increase which leads to an increase in power output. Although Bashir's investigation provided a trend of how both the monocrystalline and polycrystalline silicon perform with changing irradiance, it fell short of giving the extent to which each of the modules behaves under high and low irradiance conditions. Rosyid [9] addressed this shortfall of Bashir when he undertook a comparative performance testing of PV modules in tropical climates of Indonesia. It was determined that the power output of the three (3) PV modules used increased proportionally with increase in irradiance. The PV modules used were the monocrystalline, polycrystalline and the micromorph silicon modules. Irradiance used was in the range of
$50 \mathrm{~W} / \mathrm{m}^{2}-350 \mathrm{~W} / \mathrm{m}^{2}$. This range can be categorized as low irradiance levels. Under this condition, Rosyid observed that the increase in power output was higher in the case of the monocrystalline module, followed by the micromorph silicon module and then the polycrystalline module. This implies that for a tropical climate like that of Indonesia's, the monocrystalline silicon module is the most suitable PV module to be deployed. Although Rosyid succeeded in providing the extent to which power output of the monocrystalline and polycrystalline modules change with increasing irradiance, this was only determined under low irradiance conditions.

The above limitation of Rosyid's work was addressed in part by Nasrin et al.[10]. Nasrin et al investigated the effect of high irradiation on PV power and energy in Malaysia. The investigation was conducted under high irradiance intensity of $1,000-3,000 \mathrm{~W} / \mathrm{m}^{2}$ using a monocrystalline module. The solar irradiation was concentrated on the PV module by means of a linear Fresnel. Data was taken in the month of January 2017. From the experiment, it was observed that at high irradiation of $3,000 \mathrm{~W} / \mathrm{m}^{2}$, the electrical power increased by $190 \mathrm{~W}$ compared with $63 \mathrm{~W}$ at an irradiation level of $1,000 \mathrm{~W} / \mathrm{m}^{2}$. Ye et al. [1] investigated outdoor PV module performance under fluctuating irradiance conditions in Singapore, a tropical climate as Malaysia's. The impact of fluctuating irradiance on the following electrical parameters were analyzed: short circuit current $\left(I_{s c}\right)$, module temperature and efficiency. Five (5) different PV Module technologies were used in the conduct of that study. The module technologies used were Monoc-Si, Hetero-junction c-Si, a-Si single junction, aSi double-junction and micromorph Si. Data was collected from January to December 2011. Irradiance was categorized into low and high irradiance. Low irradiance was in the range of $200 \mathrm{~W} / \mathrm{m}^{2}-350$ $\mathrm{W} / \mathrm{m}^{2}$ while high irradiance was in the range of $900 \mathrm{~W} / \mathrm{m}^{2}-1100 \mathrm{~W} / \mathrm{m}^{2}$. In the case of mono c-Si module, it was determined that, with longer duration of stable irradiance, the average efficiency increased at low irradiance and decreased at high irradiance.

Zydb and Gulkowski [11] assessed the performance of four different PV technologies in Poland. The effect of irradiation on the temperature of the modules was investigated. The module technologies assessed were polycrystalline silicon, amorphous silicon, copper indium gallium selenide (CIGS) and cadmium telluride. It was determined that for both the warm and cold halves of the year, the temperature of the modules increased with irradiance. This was attributed to air temperature growth and direct heating of the modules surface. The rise in temperature accounted for the efficiency drop in the case of poly-c-Si and CIGS technologies. Below irradiance of $200 \mathrm{~W} / \mathrm{m}^{2}$, the efficiency of the PV modules reduced. Zydb and Gulkowski's work did not include monocrystalline silicon module which is one of the most commercially available PV module technologies 
in the world. Comparative analysis of monocrystalline and amorphous silicon was carried out in natural light for two years by Coftas et al [12] in Brasov, Romania. $P_{\max }$ was used as the key performance indicator. At low irradiance (50-350 $\mathrm{W} / \mathrm{m}^{2}$ ), the mono-c-Si silicon panel recorded gains in $P_{\max }$ almost two times larger than that of the amorphous silicon panel. Degradations of $1.02 \%$ and $1.97 \%$ were reported for the monocrystalline silicon and a-Si (amorphous silicon) panel respectively after two years in operation. Komoni et al.[13] carried out performance assessment of two mono-c-Si and poly-c-Si modules connected to the grid. Total energy generated by the mono-c-Si modules was found to be higher than the poly-cSi modules. Karama et al. [14] assessed the performance of mono-c-Si, poly-c-Si, and amorphous silicon panels in Casablanca, Morocco. The monoc-Si module was adjudged the best in terms of efficiency in both clear and cloudy days.

Aburiya et al. [15] investigated the effects of high solar irradiance and ambient temperature on solar PV module output in Northern Ghana. The modules used in this investigation were poly-c-Si and a-Si. It was concluded that high irradiance, together with temperatures between $26-30^{\circ} \mathrm{Care}$ a requirement for high panel output. There is quite a lot of research in the literature on high and low irradiance. There is however, no data on comparative study of the performance of poly-c$\mathrm{Si}$ and mono-c-Si PV module technologies at low and high irradiance in sub-Saharan Africa (SSA). In this study, the authors seek to determine the power output $\left(P_{\max }\right)$ of modules at low and high irradiance in Kumasi in order to assist PV installers determine the optimum number of modules required, particularly at low irradiance. This is because when the $P_{\max }$ at low irradiance is very low, it will affect the total energy output that is expected. For large scale utility applications, additional modules will be required to make up for the loss in $P_{\max }$. Modules with better performance at low irradiance will be preferred. Electrical performance characteristics $\left(I_{s c}, V_{o c}, P_{\max }, F F\right.$ and efficiency) of mono-c-Si and poly-c-Si PV modules under high and low irradiance levels in Kumasi, Ghana in sub-Saharan Africa is evaluated. Additionally, light induced degradation (LID) effect of the as-received modules after exposure to the natural light will be assessed. LID occurs in PV modules leading to a reduction in output power as well as a reduction in overall efficiency of the cell. Crystalline solar cells fabricated on Czochralski (CZ) wafers exhibit LID of the cell performance [16]. This effect is attributed to boron-oxygen (BO) defects in the wafer itself. This is a type of defect formed by prolonged exposure of $\mathrm{CZ}$ wafers to light. Poly-c-Si has a low concentration of oxygen and solar cells made from such materials are not expected to display significant B-O related LID defect. Researchers have, however, reported LID effect in the polycrystalline cell performance after initial exposure to light [17]. This study also seeks to evaluate the LID effects of both mono-c-Si and poly-c-Si modules. The findings could be a useful source of information during the sizing of PV modules. For example, in locations with many hours of low irradiance, knowledge of the performance at low irradiance could help in the determination of the number of PV modules that are required for the construction of a power plant.

\section{MATERIALS AND METHODS}

In this study, the performance of as-received mono-c-Si and poly-c-Si solar PV modules installed on a mounted rack facing south and tilted at an angle of $13^{\circ}$ was evaluated. The test site is the College of Engineering of the Kwame Nkrumah University of Science and Technology (KNUST) in Kumasi, Ghana. Kumasi lies on longitude $1.62^{\circ} \mathrm{W}$ and latitude $6.67^{\circ} \mathrm{N}$ at an elevation of $250 \mathrm{~m}$ above sea level. Meteorological data was obtained from the location of study using an Automatic Weather Station (SOLYS 2) manufactured by Sutron, Germany. Average annual humidity of $75.0 \%$ was recorded with a range of $70 \%-80 \%$. A daily minimum temperature range of $20.0^{\circ} \mathrm{C}-$ $22.0^{\circ} \mathrm{C}$ and a maximum range of $28.0^{\circ} \mathrm{C}-35.0^{\circ} \mathrm{C}$ were also recorded. A low wind speed averaging around $2.0 \mathrm{~m} / \mathrm{s}$ was obtained during the period of experimentation. A low wind speed can lead to an increase in module temperature and a reduction in $P_{\max }$ due to its influence on temperature coefficient and $V_{o c}$. High relative humidity can also lead to a decrease in irradiance and a reduction in maximum power output $\left(P_{\max }\right)$.

The new modules were exposed to the outdoor conditions for two hours to allow the soaking of the natural light before I-V curve tracing to determine the key performance parameters such as $P_{\max }, I_{s c}, V_{o c}, F F$ and efficiency under high and low irradiance. The low irradiance level of 200 $\mathrm{W} / \mathrm{m}^{2}$ was achieved by using a calibrated mesh screen (manufactured by TÜV Rheinland, Tempe Arizona, USA) according to IEC 60904-1 which allows irradiance transmittance of $200 \mathrm{~W} / \mathrm{m}^{2}$ (Belmont, 2013). I-V curve tracing is a method of analyzing the performance of a PV module or array, ideal for testing all possible operating points of a PV module or string of modules [17]. The high irradiance tests were taken followed by the low irradiance tests which was accomplished by covering the module with the calibrated mesh screen. The tests were repeated and the average values taken. Figure ?? shows the bare PV module and PV module with screen mesh before the I-V curve tracing.

\subsubsection{Module Technologies}

Two as-received PV modules of different technologies were employed in this study. These were mono-c-Si and poly-c-Si modules manufactured by Just Solar, China. These modules were selected as they account for about $89 \%$ of the global market [18] and are also reported to have higher efficiencies and stability [19]. Table 1 details the technical specification at STC of the PV module technologies used in this study. 
Table 1: Technical Specification of PV modules (Manufacturer nameplate ratings).

\begin{tabular}{lcc}
\hline Parameter & $\begin{array}{c}\text { PV Module Technology } \\
\text { Mono-c-Si }\end{array}$ & Poly-c-Si \\
\hline Efficiency & $16.51(\%)$ & $14.49(\%)$ \\
Max. Power (W) & $100(\mathrm{Wp})$ & $150(\mathrm{Wp})$ \\
Area & $0.606\left(\mathrm{~m}^{2}\right)$ & $1.035\left(\mathrm{~m}^{2}\right)$ \\
Impp (A) & $5.56(\mathrm{~A})$ & $8.11(\mathrm{~A})$ \\
Vmpp (V) & $18.0(\mathrm{~V})$ & $18.5(\mathrm{~V})$ \\
Isc (A) & $5.85(\mathrm{~A})$ & $8.56(\mathrm{~A})$ \\
Voc (V) & $21.50(\mathrm{~V})$ & $22.5(\mathrm{~V})$ \\
Maximum System voltage & $1000(\mathrm{~V})$ & $1000(\mathrm{~V})$ \\
\hline
\end{tabular}

\subsubsection{Measuring instruments and materials}

The current-voltage (I-V) curve tracing was carried out using TRI-KA analyzer in conjunction with TRI-SEN sensing device manufactured by TRIKA, Basel in Switzerland. The TRI-SEN measures the irradiation, cell temperature and angle of inclination and wirelessly transfer the data to the TRI-KA. The field data is used to convert (extrapolate or normalize) the characteristic curve measured by the TRI-KA into a STC characteristic curve (STC_-Standard Test Conditions: irradiation $1000 \mathrm{~W} / \mathrm{m}^{2}$, spectrum air mass $(\mathrm{AM})=1.5$, module temperature $\left.25^{\circ} \mathrm{C}\right)$. The calibrated mesh screen was used to block out specific amount of irradiance allowing only $200 \mathrm{~W} / \mathrm{m}^{2}$ to pass through according to IEC 60904_1.

LID, which is a very important performance parameter of PV modules after the initial few hours of exposure to light was ascertained using Eq. (1).

$$
\begin{aligned}
& \% P_{\text {max }} d \text { rop }= \\
& \frac{\text { manufacturer rated }(\mathrm{W})-\text { present day }(\mathrm{W})}{\text { manufacturer rated }(\mathrm{W})} \\
& \times 100 \%
\end{aligned}
$$

The $\% I_{s c}$ and $\% V_{o c}$ drops can similarly be determined using Eq. (2) and (3) respectively.

$$
\% I_{s c} d r o p=
$$

manufacturer rated (A)- present day(A) manufacturer rated (A)

$$
\times 100 \%
$$

$$
\% V_{o c} d r o p=
$$

manufacturer rated $(\mathrm{V})$ - present $\operatorname{day}(\mathrm{V})$

$$
\text { manufacturer rated }(\mathrm{V}) \quad \times 100 \%
$$

Where, $\% P_{\max }$ drop is the percentage drop in maximum power, manufacturer rated is the nameplate rating indicated in Table 1 and the present day being the current measured value.

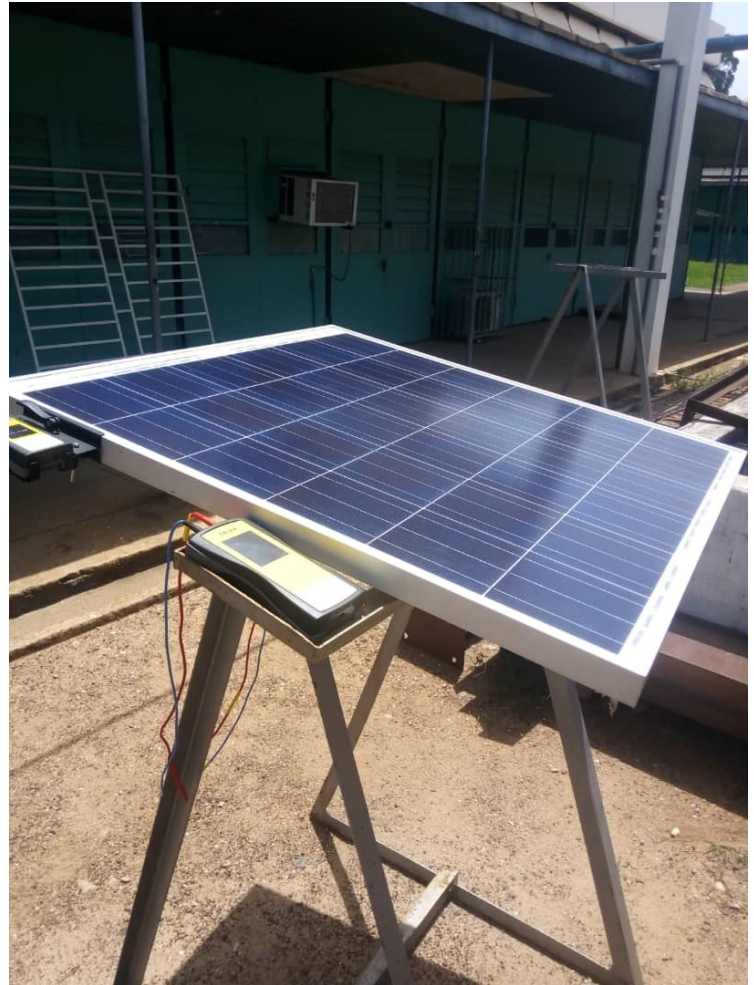

(a) Bare PV module .
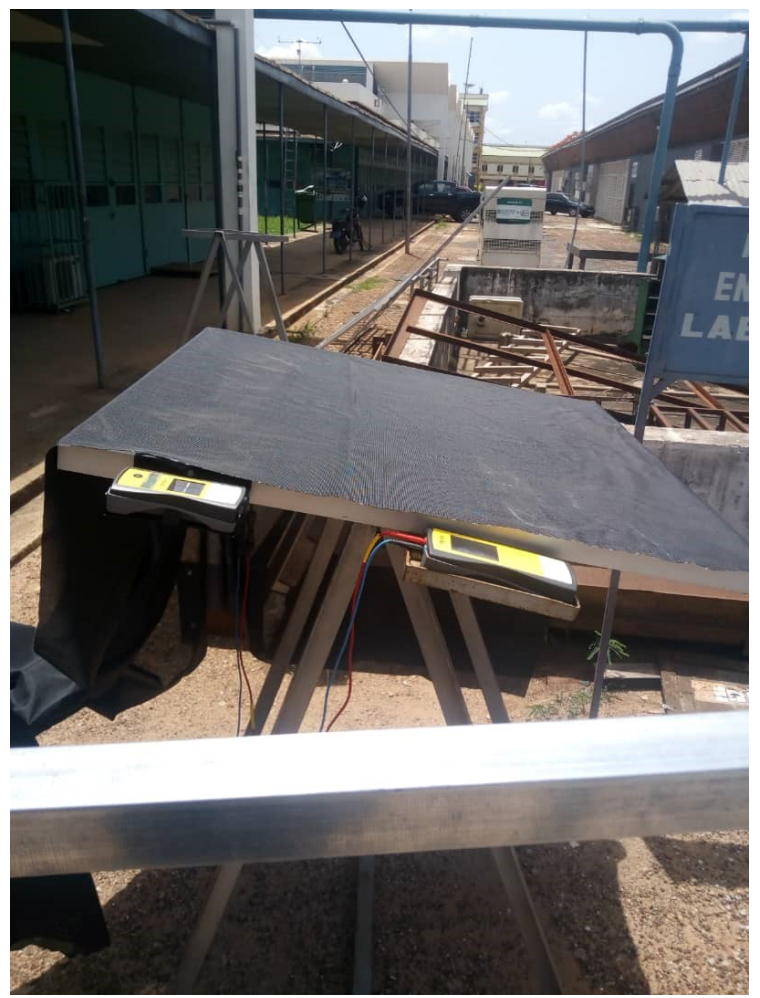

(b) PV module with mesh screen

Figure 1: Photographs showing experimental setup for (a) bare PV module (b) PV module with mesh screen 


\section{RESULTS}

This section presents the results of the various electrical characteristics $\left(I_{s c}, V_{o c}, P_{\max }, F F\right.$ and efficiency) that were considered in this study.

\subsection{I-V Characteristic Curves for the Mono-c- Si Module at High and Low Irradiance}

Figures $2 \mathrm{a}$ and $22 \mathrm{~b}$ show the I-V characteristic curves at low irradiance for the mono-c-Si module indicated as trial 1 and trial 2 (for the repeat tests). The I-V curve for the raw data is indicated in green colour and the STC or normalized curve indicated in red in the legend. The normalized or extrapolated curve is the raw data taken from the field that has been normalized to STC conditions. For example, irradiance of $700 \mathrm{~W} / \mathrm{m}^{2}$ and temperature of $38^{\circ} \mathrm{C}$ were normalized to $1,000 \mathrm{~W} / \mathrm{m}^{2}$ and $25^{\circ} \mathrm{C}$ (STC conditions) respectively by the TRI-KA Software. The PUI raw and PUI STC are the power curves for the raw data and STC or normalised data respectively. These are indicated at the bottom with the power axis on the right side. For example, the maximum power on the PUI STC curve for mono-c-Si at low irradiance is around 7.8 $\mathrm{W}$ (the top of the two power curves), whilst that for PUI raw data is estimated around $7 \mathrm{~W}$ (bottom of the two power curves). The design of the calibrated mesh screen ensured a transmittance of about $200 \mathrm{~W} / \mathrm{m}^{2}$ of irradiance to the PV module surface, which is evidenced by the low values, especially $P_{\max }$ recorded for the electrical characteristics. Figures $3 a$ and $3 b$ show the I-V curves of the mono-c-Si at high irradiance. Table 2 shows the efficiencies obtained for the high and low irradiance tests using Eq. (4). The high irradiance test yielded efficiency of $19.2 \%$ for the mono-c-Si modules whilst the low irradiance test yielded an average value of $6.78 \%$.

$$
\operatorname{Efficiency}(\eta)=\frac{\operatorname{Power}(\mathrm{W})}{\operatorname{Irradiance}\left(\frac{W}{m^{2}}\right) \times \text { Area of module } m^{2}}
$$

\subsection{I-V Characteristic Curve for the Poly-c-Si Module at High and Low Irradiance}

Similarly, for the poly-c-Si module, I-V characteristic curves were taken for high and low irradiance levels. Figures $4 \mathrm{a}$ and $4 \mathrm{~b}$ depict the I-V curves for the low irradiance conditions. Again, Fig. $4 \mathrm{a}$ and $4 \mathrm{~b}$ are the repeat of the same experiment (indicated as trial 1 and trial 2). Figures 5a and $5 \mathrm{~b}$ show the I-V curves for the high irradiance level. Table 2 also shows the efficiencies obtained for the high irradiance and low irradiance tests for the poly-c-Si module. The efficiencies were similarly calculated using Eq. 4 as $14.29 \%$ at high irradiance and an average of $5.85 \%$ at low irradiance.

Figures 6 through 8 show the I-V characteristics ( $I_{s c}, V_{o c}, P_{\max }$ and Fill factor) against the type of PV module technology.

\section{DISCUSSION}

This section provides detailed discussions of the key parameters used for the assessment. These include: short circuit current $\left(I_{s c}\right)$, open circuit voltage $\left(V_{o c}\right), P_{\max }$, efficiency, fill factor $(\mathrm{FF})$ and LID effect.

\section{1. $I_{s c}$ at High and Low Irradiance}

Figure 6 shows the average $I_{s c}$ variation at high and low irradiance. The average $I_{s c}$ value measured for the mono-c-Si module at low irradiance was $0.6075 \mathrm{~A}$. The results show an average high irradiance value of $5.37 \mathrm{~A}$, representing a percentage reduction of $88.7 \%$ from high to low irradiance. A similar trend was observed for the poly-cSi module. $I_{s c}$ reduced from an average value of $8.39 \mathrm{~A}$ to an average value of $0.85 \mathrm{~A}$ (representing a reduction of $89.9 \%$ ). These results confirm the strong dependence of Isc on irradiance reported by $[6,20,21]$.

\section{2. $V_{o c}$ at High and Low Irradiance}

In the case of the mono-c-Si module (shown in Fig. 7), high irradiance produced a $V_{o c}$ of $22.4 \mathrm{~V}$ which decreased to an average value of $19.60 \mathrm{~V}$ at low irradiance (representing a percentage reduction of $12.5 \%$ ). With regards to the poly-c-Si module, the $V_{o c}$ decreased from an average value of $22.02 \mathrm{~V}$ at high irradiance to $19.26 \mathrm{~V}$ at low irradiance (also representing a reduction of $12.5 \%$ ). The loss of $V_{o c}$ is generally attributed to degradation of the cells and shunting problems [22]. Since this is a new module, cell shunting and not degradation could be the possible cause of Voc loss. The relatively small percentage change from high to low irradiance shows that the effect of irradiance on $V_{o c}$ is not as great as it is on $I_{s c}$. This is consistent with several work reported in the literature including [6].

\subsection{Maximum Power $\left(P_{\max }\right)$ at High and Low Irradiance}

The Mono-c-Si module recorded $P_{\max }$ average of $84.6 \mathrm{~W}$ at high irradiance and an average of 8.22 $\mathrm{W}$ for the low irradiance condition representing a reduction of $90.3 \%$ as shown in Fig. 8. Similarly, in the case of the poly-c-Si module, the average maximum power output $\left(P_{\max }\right)$ at high irradiance of $136.7 \mathrm{~W}$ reduced greatly to an average of $12.09 \mathrm{~W}$ (representing $91.20 \%$ reduction). The effect of shunt resistance becomes important under low irradiance conditions. When there is less light generated, the series resistance of the solar cell approaches the shunt resistance. This leads to an increase in power loss as a result of the shunt resistance [7]. These results indicate that when the irradiance drops for example, from a high value of $1,000 \mathrm{~W} / \mathrm{m}^{2}$ to $200 \mathrm{~W} / \mathrm{m}^{2}$ and below, the PV modules operate around 9\% to $10 \%$ of their capacities. This has implications for the number of modules that are required for installation in areas that experience many hours of low irradiance. Knowledge of the performance at low irradiance will enable the determination of the actual number of modules required during the sizing of PV plants. 


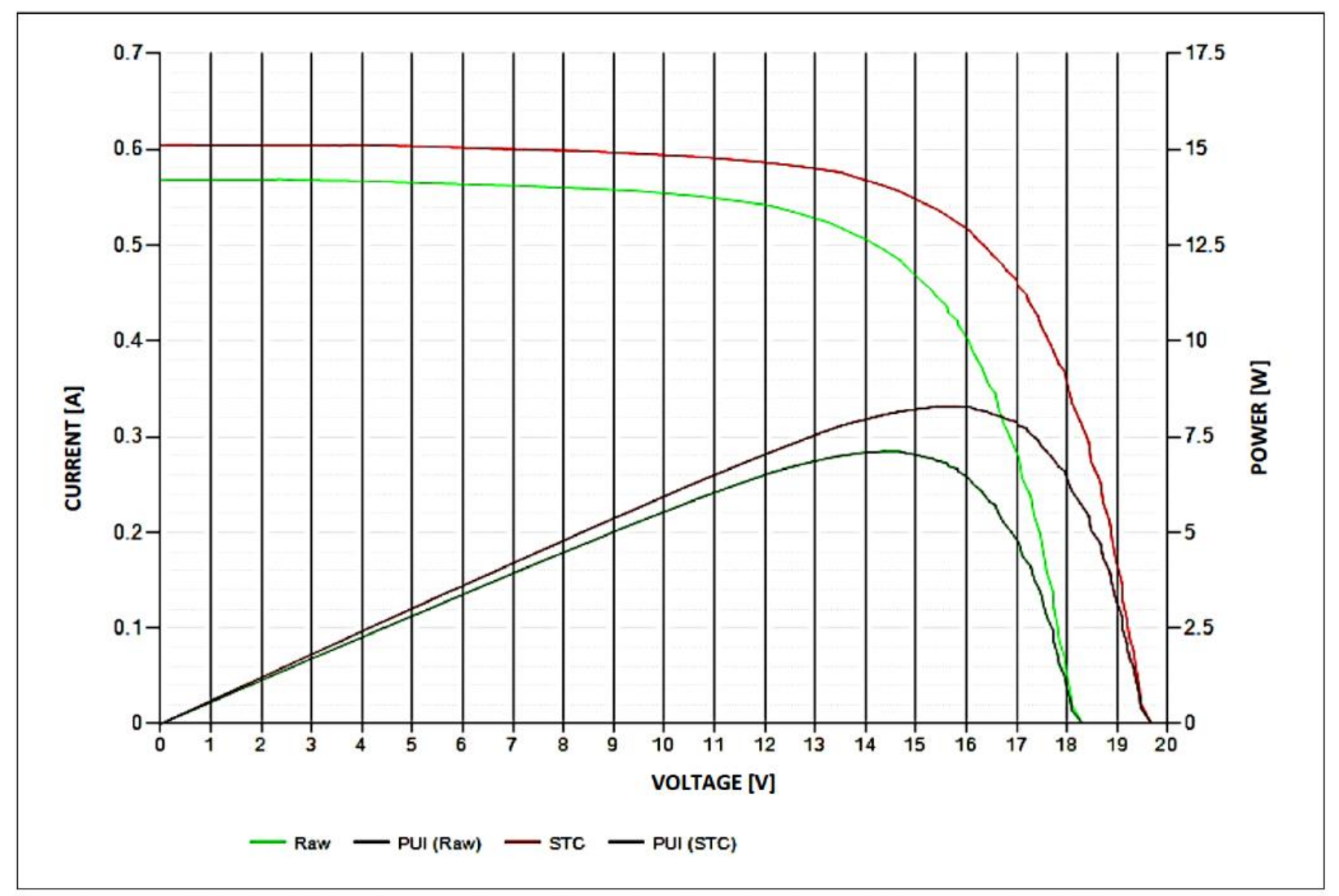

(a) (trial 1) I-V Characteristic Curve for the Mono-c-Si Module at Low Irradiance

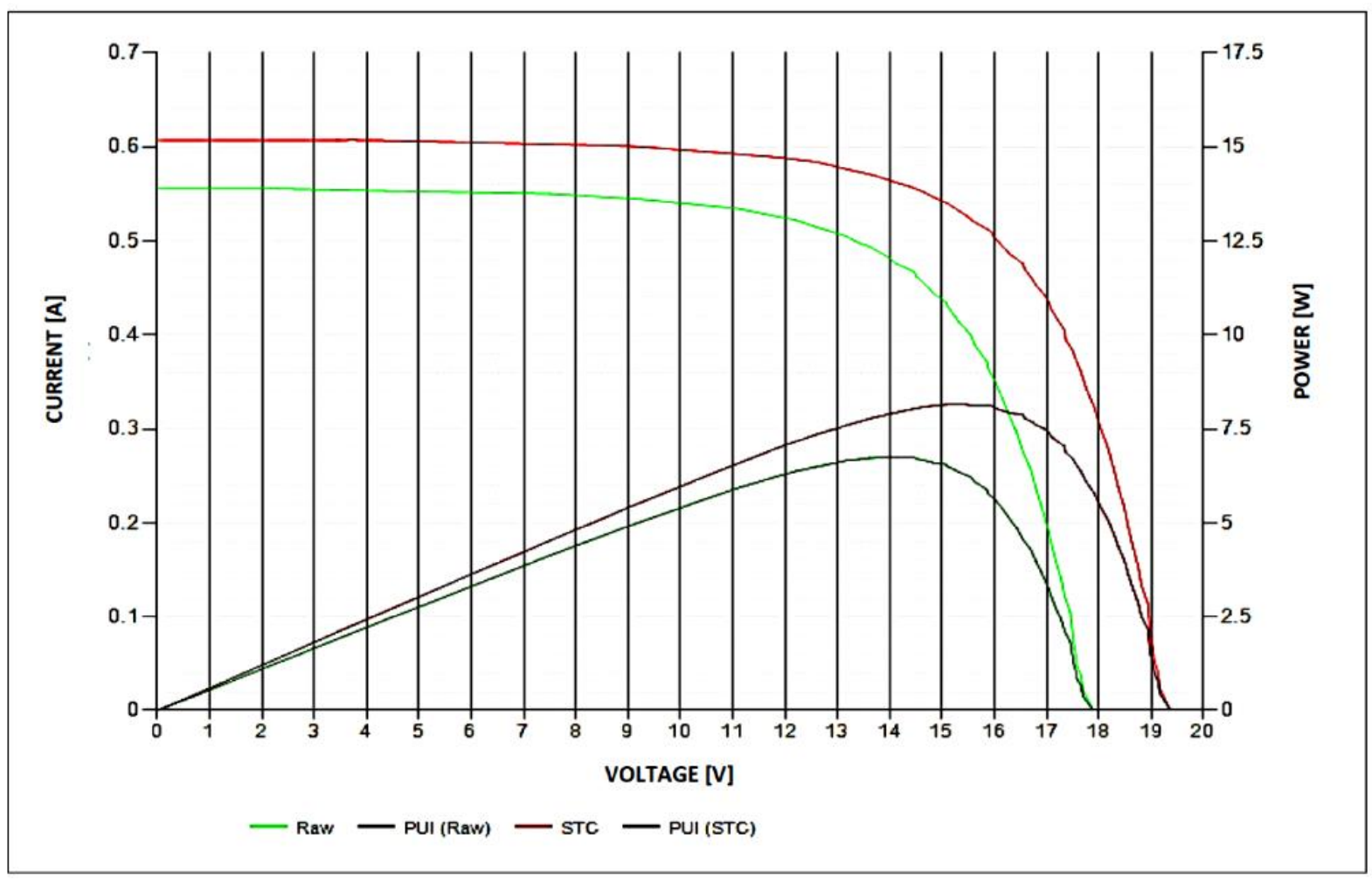

(b) (trial 2) I-V Characteristic Curve for the Mono-c-Si Module at Low Irradiance

Figure 2: (a) (trial 1) I-V Characteristic Curve for the Mono-c-Si Module at Low Irradiance and (b) (trial 2) I-V Characteristic Curve for the Mono-c-Si Module at Low Irradiance. 


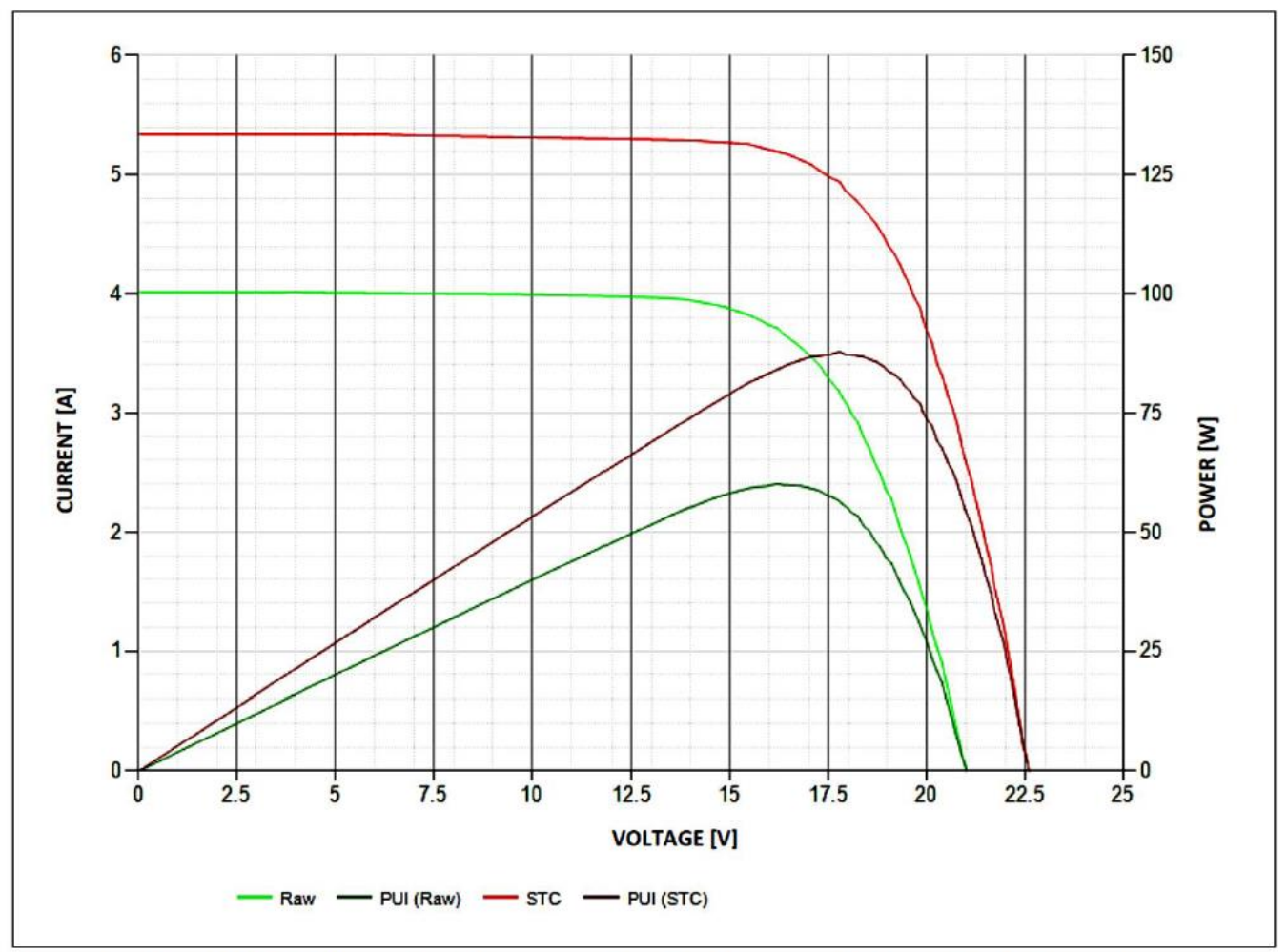

(a) (trial 1) I-V Characteristic Curve for the Mono-c-Si Module at High Irradiance

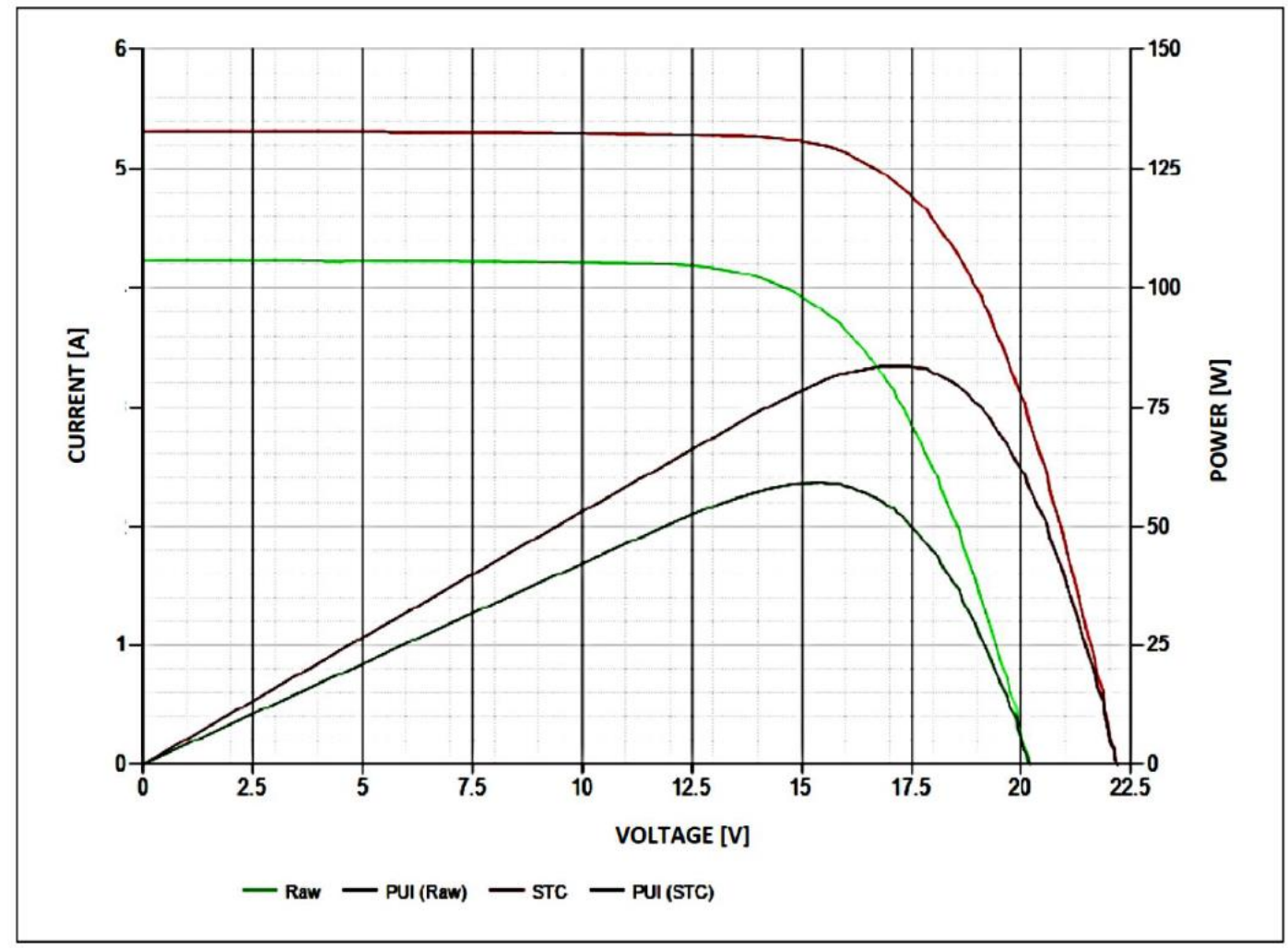

(b) (trial 2) I-V Characteristic Curve for the Mono-c-Si Module at High Irradiance

Figure 3: (a) (trial 1) I-V Characteristic Curve for the Mono-c-Si Module at High Irradiance and (b) (trial 2) I-V Characteristic Curve for the Mono-c-Si Module at High Irradiance . 


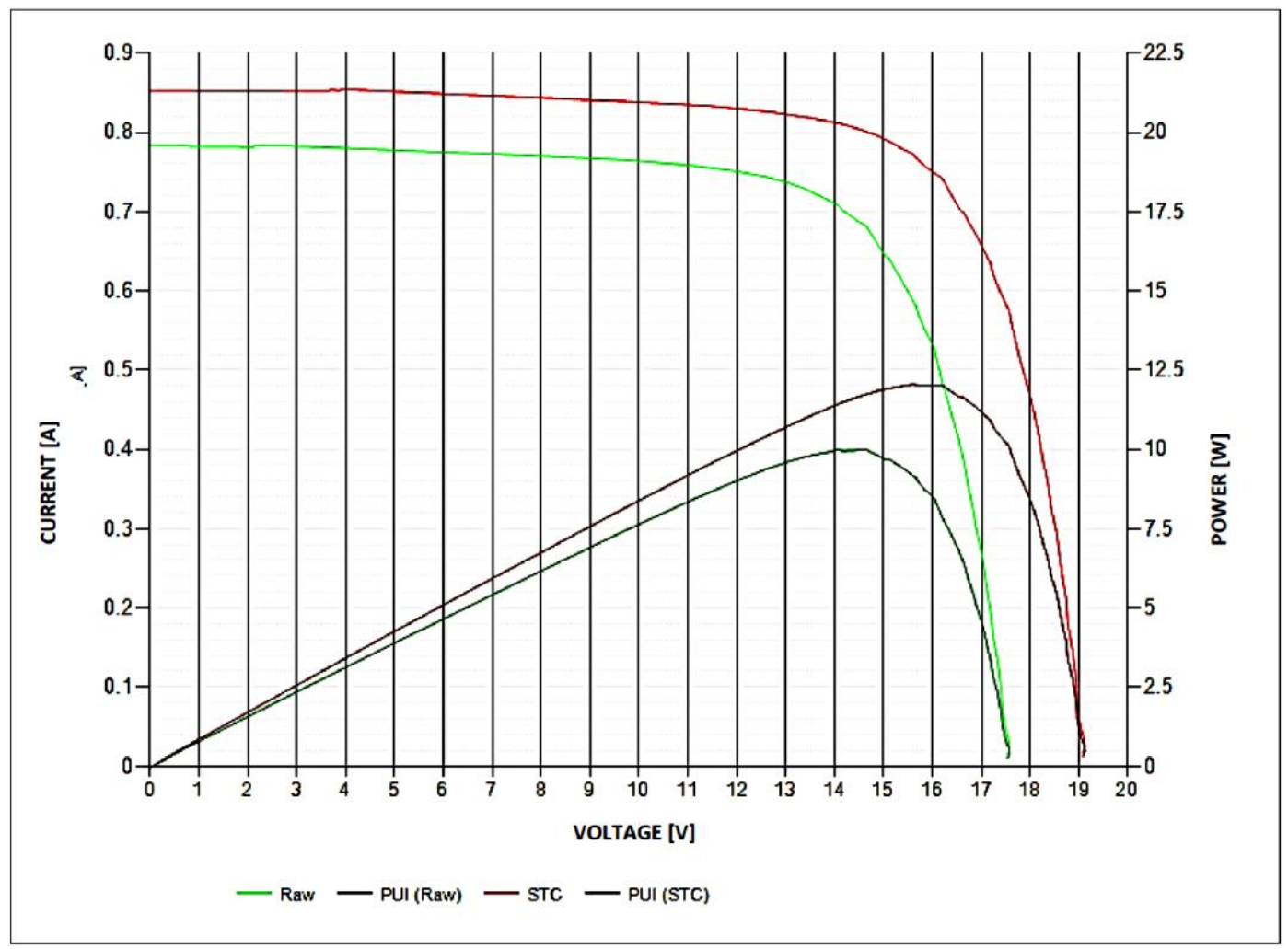

(a) (trial 1) I-V Characteristic Curve for the Poly-c-Si Module at Low Irradiance

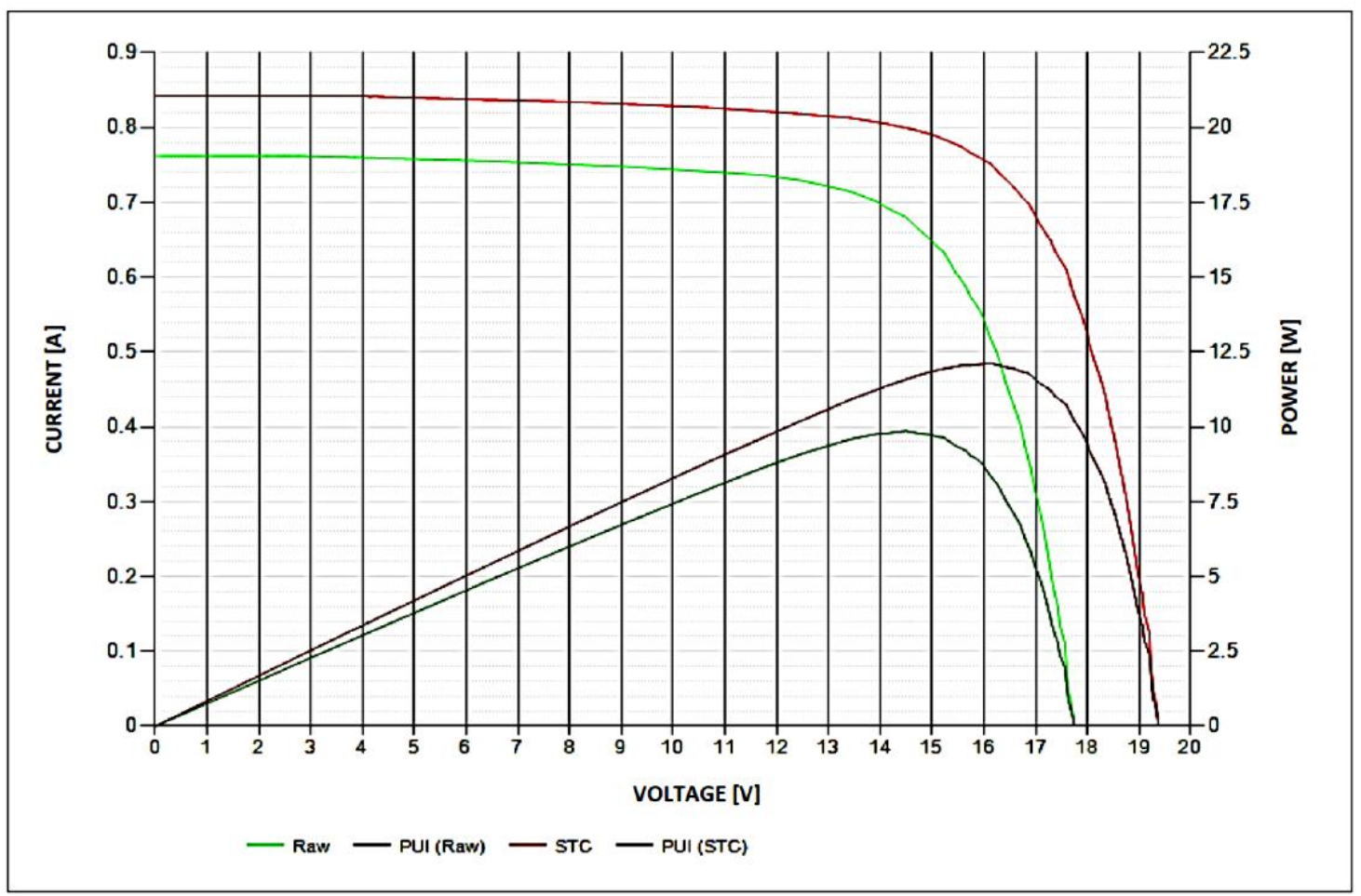

(b) (trial 2) I-V Characteristic Curve for the Poly-c-Si Module at Low Irradiance

Figure 4: (a) (trial 1) I-V Characteristic Curve for the Poly-c-Si Module at Low Irradiance and (b) (trial 2) I-V Characteristic Curve for the Poly-c-Si Module at Low Irradiance . 


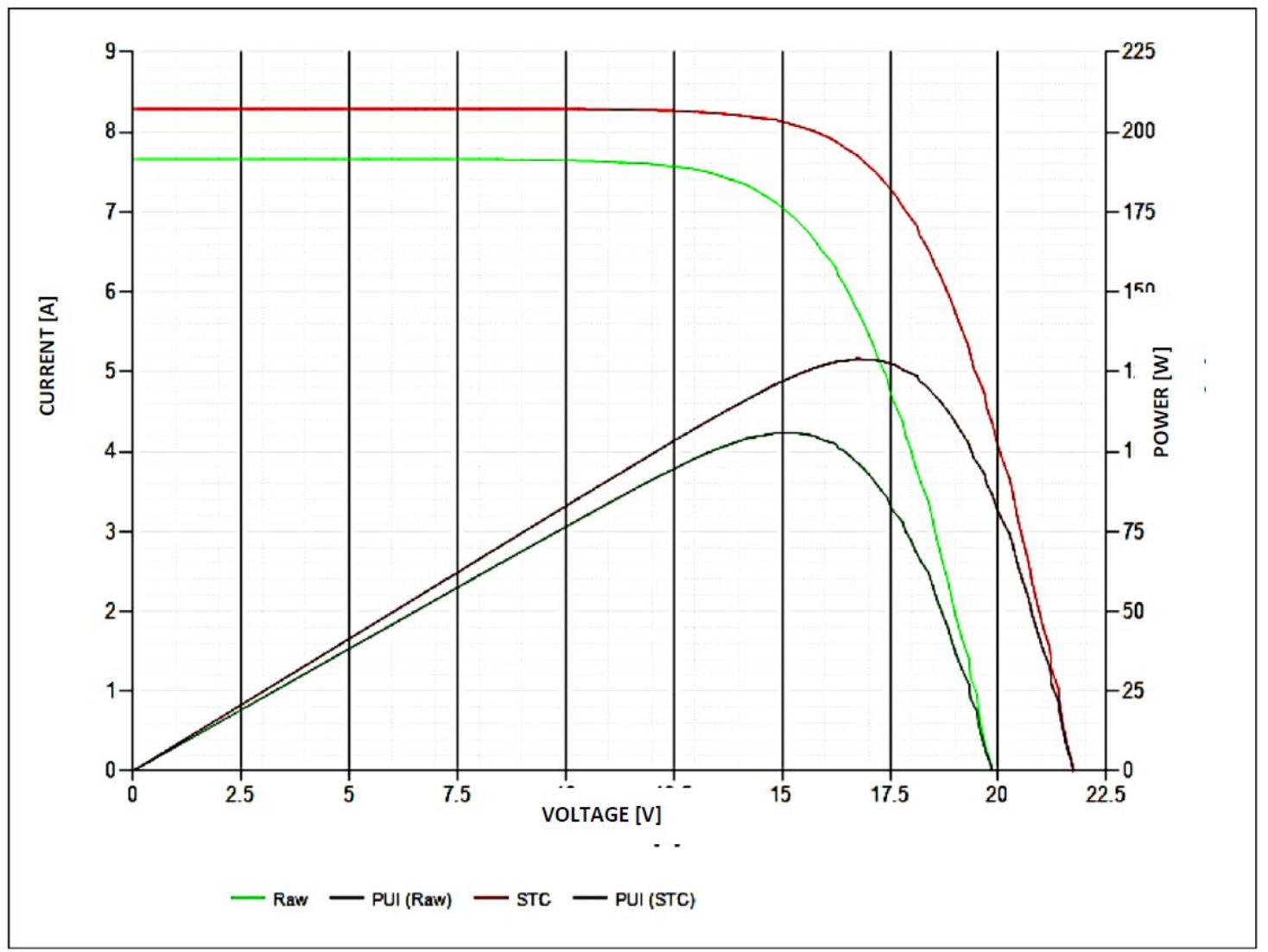

(a) (trial 1) I-V Characteristic Curve for the Poly-c-Si Module at High Irradiance

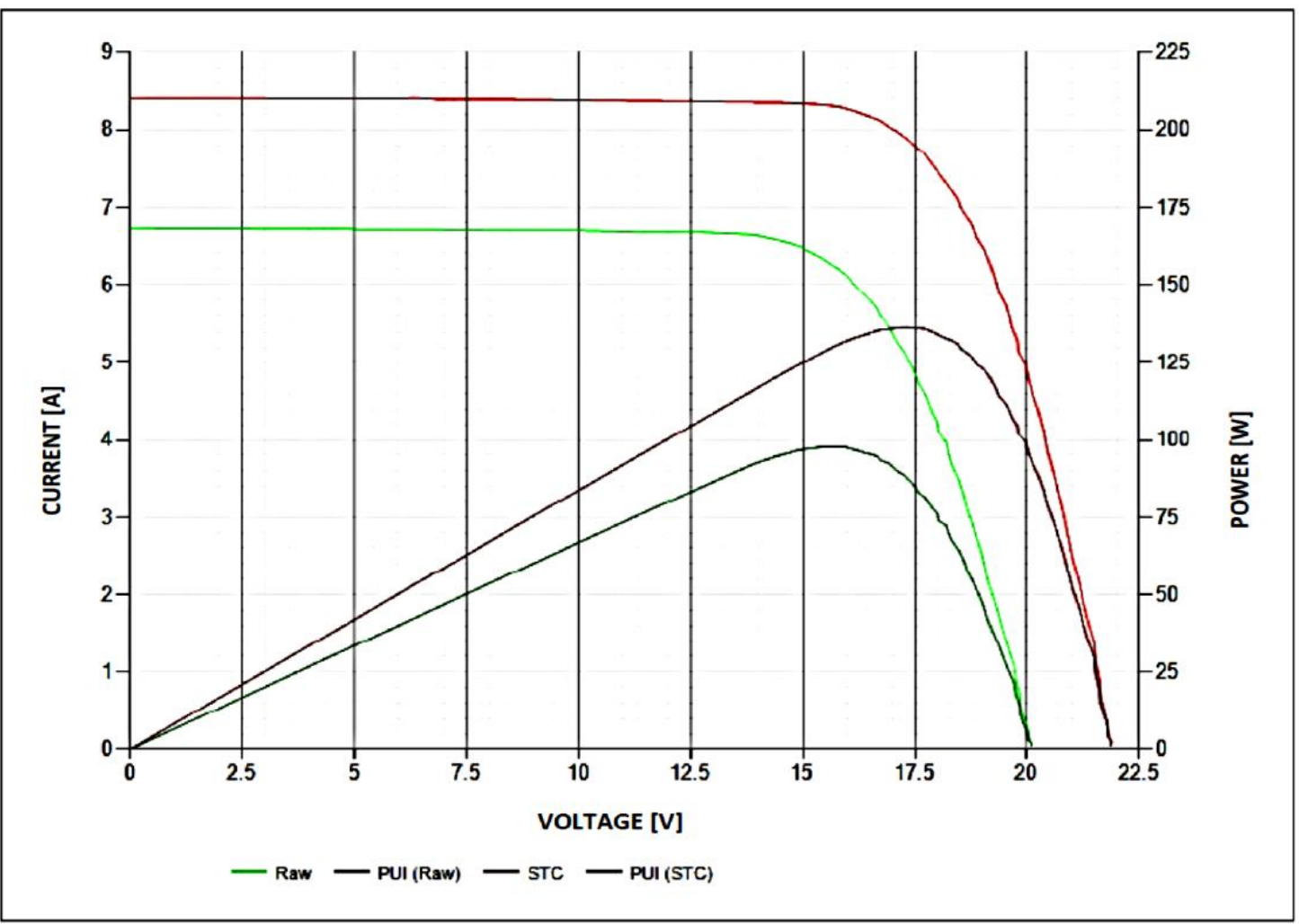

(b) (trial 2) I-V Characteristic Curve for the Poly-c-Si Module at High Irradiance

Figure 5: (a) (trial 1) I-V Characteristic Curve for the Poly-c-Si Module at High Irradiance and (b) (trial 2) I-V Characteristic Curve for the Poly-c-Si Module at High Irradiance 


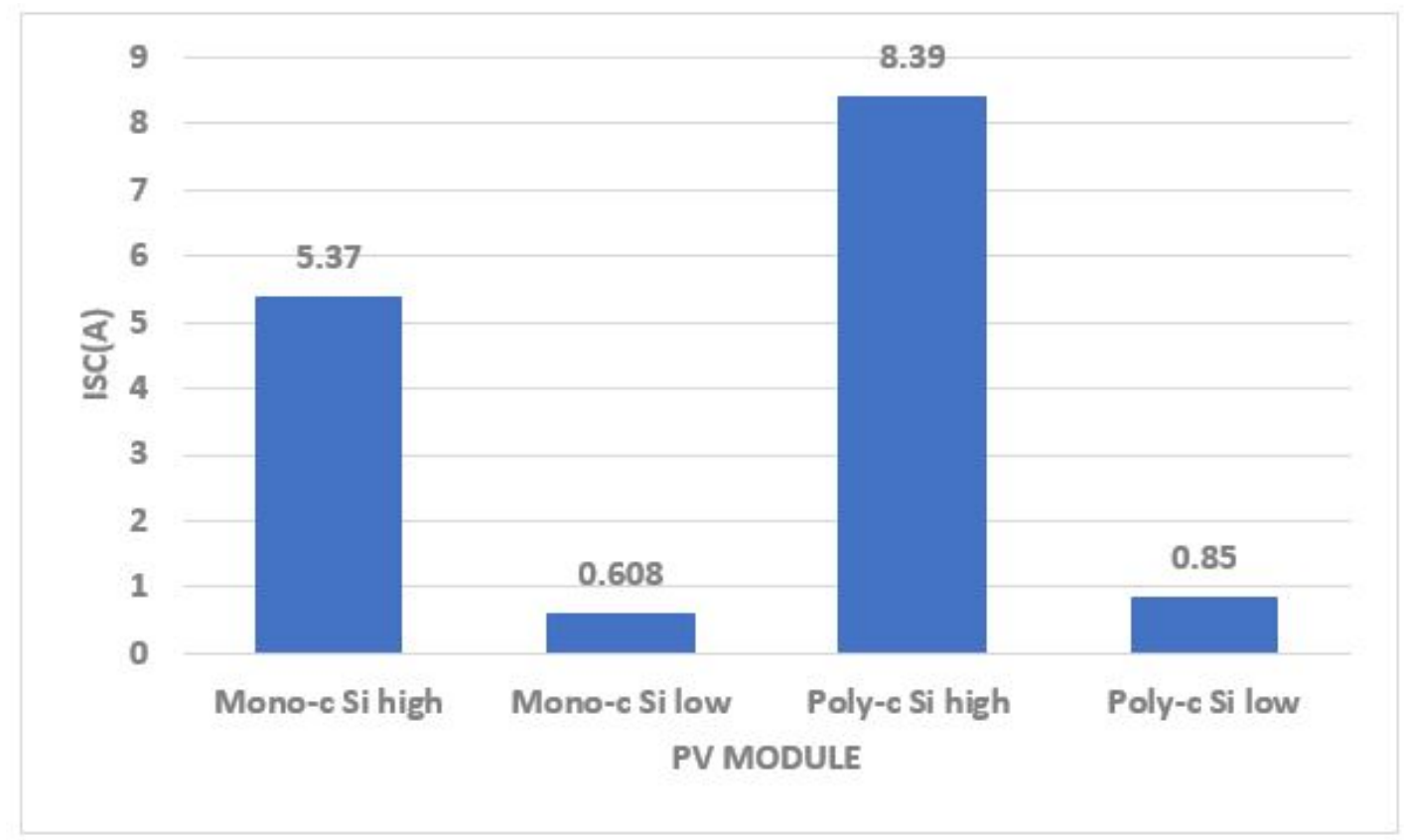

Figure 6: $I_{S c}$ vs PV Module Technologies at Low and High Irradiance.

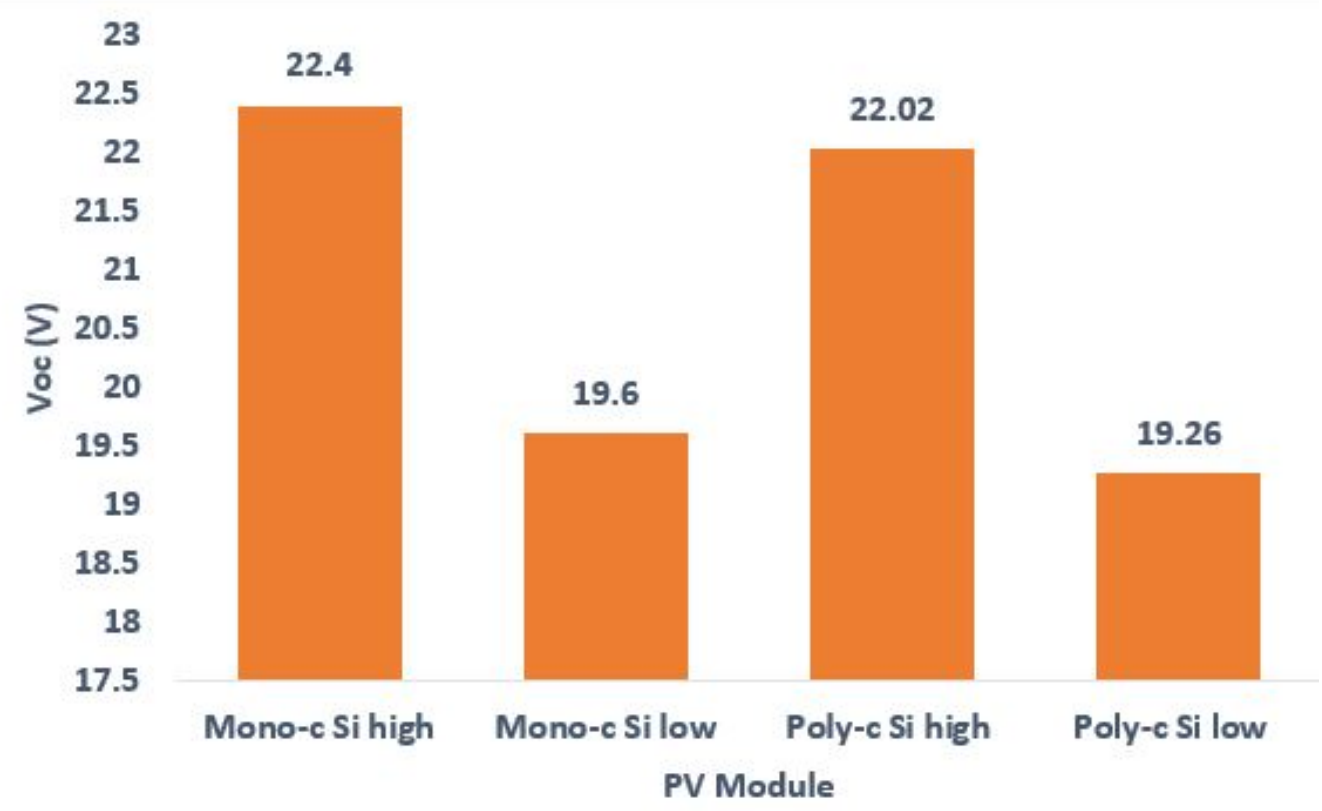

Figure 7: $V_{o c}$ vs PV Module Technologies at Low and High Irradiance.

Table 2: Efficiency and data used in calculation.

\begin{tabular}{llcccc}
\hline Moule Technology & Irradiance (High/low) & $\mathbf{P}_{\max }(\mathrm{W} /)$ & $P_{\max }$ drop (\%) & Irradiance $\left(\mathrm{W} / \mathrm{m}^{2}\right)$ & Efficiency $(\%)$ \\
\hline \multirow{4}{*}{ Mono-c-Si } & 87.9 & 12.1 & 752 & $19.29 \%$ \\
& High & & & & \\
& Low & 8.29 & 91.71 & 200 & $6.84 \%$ \\
& Trial 1 & & & & \\
& Low & 8.15 & 91.85 & 200 & $6.72 \%$ \\
& Trial 2 & 8.22 & 91.78 & 200 & $6.78 \%$ \\
& Average (trial 1 \& 2) & 136.7 & 8.86 & 924 & $14.29 \%$ \\
Poly-c-Si & High & 12.13 & 91.91 & 200 & $5.86 \%$ \\
& Low & & & & \\
& Trial 1 & & & 200 & $5.83 \%$ \\
& Low & 12.06 & 91.96 & 200 & $5.85 \%$ \\
\hline
\end{tabular}




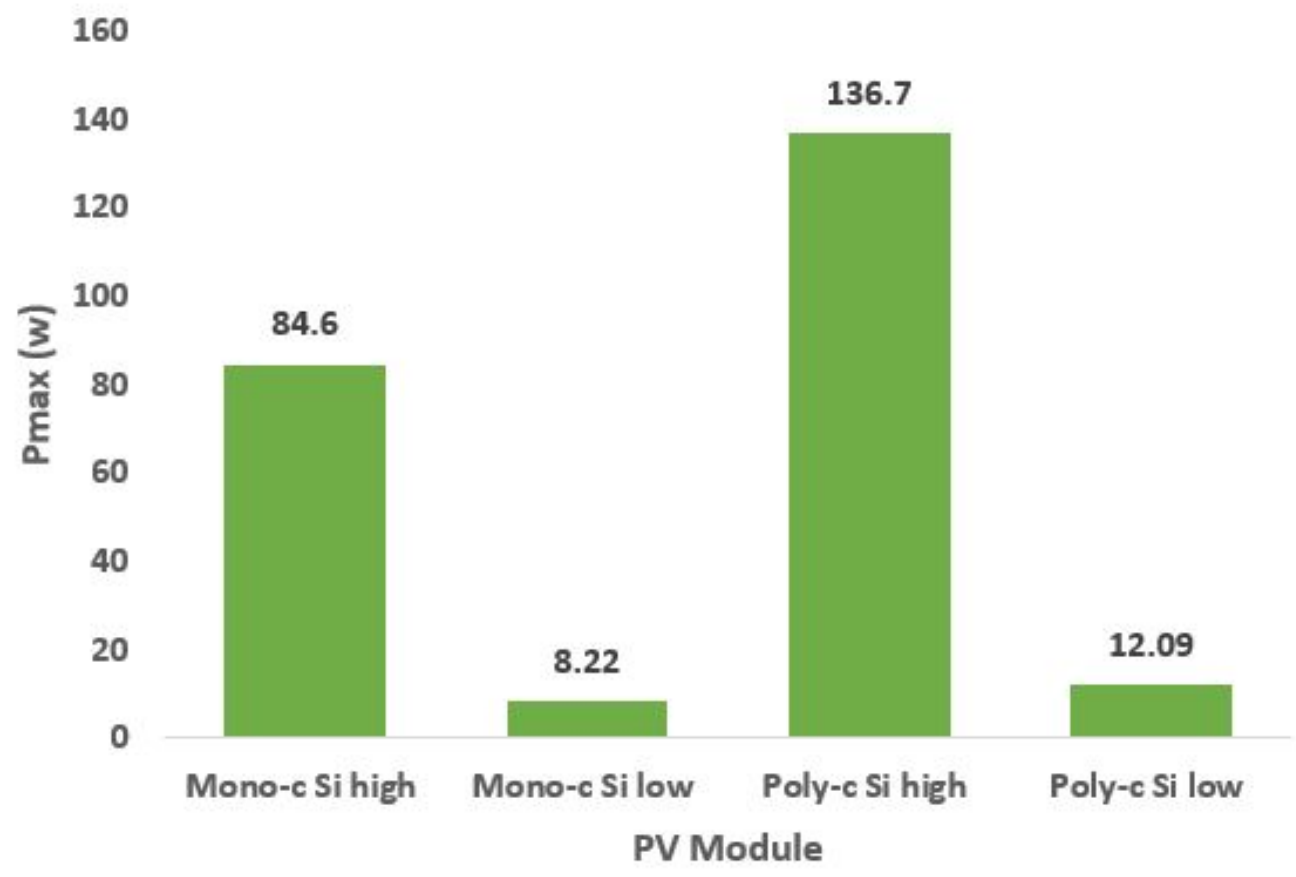

Figure 8: $P_{\max }$ vs PV Module Technologies at Low and High Irradiance.

\subsection{Fill Factor at High and Low Irradiance}

Figure 9 shows the fill factor for the two technologies at low and high irradiance. Fill factor of 0.72 was recorded at high irradiance which decreased by just $4.17 \%$ to 0.69 at low irradiance conditions. Whereas FF decreased slightly in the case of the mono-c-Si module, the poly-c-Si module saw no change in FF. Both high and low irradiance conditions of the poly-c-Si module recorded FF of 0.74 . This implies that in terms of the FF, the poly-c-Si module performs better at both high and low irradiance than the mono-c-Si module. This is possibly due to the effect of light induced degradation (LID) since the modules are new. Light induced degradation is a loss of performance arising from the very first hours of exposition to the sun with crystalline modules. The degradation is characterized through the knowledge of the evolution of parameters such as $V_{o c}, I_{s c}$ and FF. LID is known to affect high efficiency mono-cSi cells more than poly-c-Si. The main problem of solar cells manufactured on Czochralski-grown monocrystalline silicon $(\mathrm{Cz}-\mathrm{Si})$ is that their initial efficiency degrades under illumination until a stable performance level is reached. LID causes a decrease in the solar cell $I_{s c}$ and the $V_{o c}$ [23], which emanates from an increase in minority-carrier recombination in the crystalline silicon lattice [24].

\subsection{Efficiency at High and Low Irradiance}

Table 1 shows the nameplate efficiencies of $16.51 \%$ and $14.49 \%$ for the mono-c-Si and poly-cSi modules respectively. These values are based on the STC conditions $\left(1,000 \mathrm{~W} / \mathrm{m}^{2}, 25^{\circ} \mathrm{C}\right.$ and 1.5 A.M). In this section, we compare the efficiencies of the calculated values (not with the nameplate ratings) in order to ascertain which technology performs better. Calculated efficiency using field data for the mono-c-Si module yielded a value of $19.29 \%$ at high irradiance (this is greater than the nameplate rating of $16.51 \%$ ), reducing to an average of $6.78 \%$ at low irradiance. This represents a percentage reduction of $64.9 \%$. The poly-c-Si module recorded efficiency of $14.29 \%$ at high irradiance (less than the nameplate rating of $14.49 \%$ ), reducing to an average of $5.85 \%$ at low irradiance, representing a reduction of $59.01 \%$. These results show that the performance of the two technologies at low irradiance are very close. The same reason given above for the $\mathrm{FF}$ with regards to the effect of LID also applies to the efficiency at high and low irradiance conditions. The LID effect may have contributed to the slightly higher reduction in efficiency of the mono-c-Si than the poly-c-Si module.

\subsection{LID Determination at High and Low Ir radiance}

The LID was determined by using the value of the $P_{\max }$ drop shown in Eq. (1). For example, the manufacturer $P_{\max }$ ratings for mono-c-Si and poly-c-Si modules are $100 \mathrm{Wp}$ and $150 \mathrm{Wp}$ respectively (see Table 1). These resulted in $P_{\max }$ drops of $12.1 \%$ and $8.6 \%$ respectively. This indicates that the mono-c-Si has been affected more by LID than the poly-c-Si module after a couple of hours of exposure to the natural light. This is corroborated by the findings of a student's project work on LID comparing mono-c-Si and poly-c-Si modules in Kumasi [25]. The results of that project indicate a percentage drop in power of $14.4 \%$ for the mono-c-Si module and 6.7\% drop in the case of the poly-c-Si module. The report concluded that the drop was due to the degradation of $\mathrm{FF}$. 


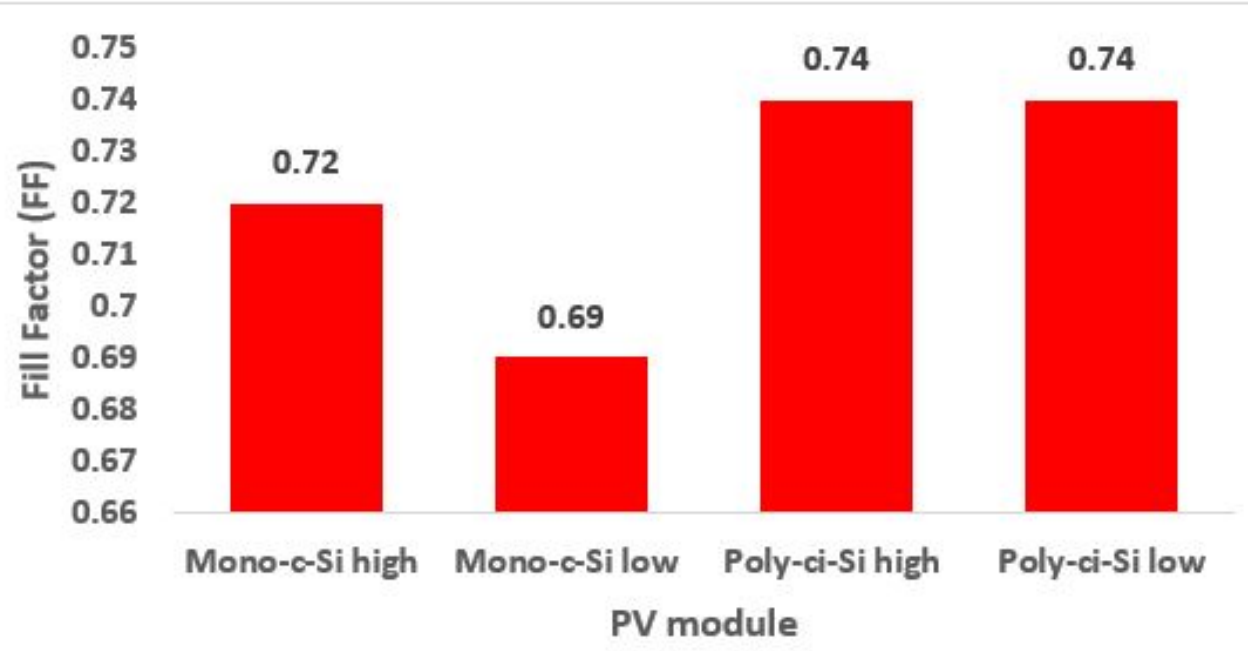

Figure 9: Fill factor (FF) vs PV Module Technologies at Low and High Irradiance.

\section{CONCLUSION}

This study sought to investigate the electrical performance of mono-c-Si module and poly-c-Si modules at high irradiance $\left(750-1,000 \mathrm{~W} / \mathrm{m}^{2}\right)$ and low irradiance $\left(200 \mathrm{~W} / \mathrm{m}^{2}\right)$ conditions using I-V curve tracing. The low irradiance condition was attained by covering the modules with a calibrated mesh screen that reduces the irradiance transmissivity to about $200 \mathrm{~W} / \mathrm{m}^{2}$ according to IEC 60490_1 standard. The I-V data is further used to ascertain the LID effects of both mono-cSi and poly-c-Si modules in SSA ambient.

The following conclusions can be drawn from the results of the study:

- The mono-c-Si and poly-c-Si modules respond in a similar manner to low irradiance levels. The electrical parameters $\left(I_{s c}, V_{o c}\right.$ and FF, $\left.P_{\max }\right)$ and percentage reductions recorded for both module technologies were very close at low irradiance.

- The results show that significant amount of power (about 90\%) is lost at low irradiance. It is important for the investor and system installers to know the performance of the modules at low irradiance and this technique has provided a means for ascertaining that. The results generally indicate that when the irradiance drops to $200 \mathrm{~W} / \mathrm{m}^{2}$ and below, the PV modules generate around $10 \%$ of their nominal power capacities. This has implications for the number of modules that are required for installation in areas that experience many hours of low irradiance.

- Efficiencies of the mono-c-Si and poly-c-Si module have been presented. The results show slightly higher reduction in efficiency of the mono-c-Si at low irradiance than the polyc-Si module. The higher drop in efficiency of the mono-c-Si module could be due to the LID effect which is more pronounced in mono-cSi cells than in poly-c-Si cells during the first few hours of exposure to light. This is possibly due to the Boron-Oxygen LID effect which is dominant in CZ mono-c-Si cells and less in poly-c-Si cells due to the low oxygen content in poly-c-Si cells.

This work has provided a concise means for determining the amount of power (that is the percentage of the nominal power) the modules will generate at low irradiance as well as their efficiencies. This information will be beneficial for designers and installers during the sizing of the PV modules for large scale applications. The novelty of this work is that knowledge of the performance at low irradiance will enable the determination of the actual number of modules required during the sizing of PV plants. Further detailed work is required to investigate the effect of temperature on the two technologies at both high and low irradiance.

\section{ACKNOWLEDGEMENT}

The authors would like to acknowledge the financial support received from the USAID for the PRESSA project Sub-Grant no. 2000004829 through the US National Academy of Sciences.

\section{References}

[1] J. Ye, K. Ding, R. Thomas, and A. Aberlea, "Outdoor PV module performance under fluctuating irradiance conditions in tropical climates," Energy Procedia, vol. 33, pp. 238-247, 2013.

[2] S. Hamou, S. Zine, and R. Abdellah, "Efficiency of PV module under real working conditions," Energy Procedia, vol. 50, pp. 553-558, 2014.

[3] S. Pervaiz and H. Khan, "Low irradiance loss quantification in c-Si panels for photovoltaic systems," Journal of Renewable and Sustainable Energy, vol. 7, no. 1, 2015.

[4] F. Mavromatakis, F. Vignolab, and B. Marion, "Low irradiance loss quantification in c-Si panels for photovoltaic systems," Solar Energy, vol. 157, pp. 496-506, 2015 . 
[5] M. Chegaar, A. Hamzaoui, A. Namoda, P. Petit, M. Aillerie, and A. Herguth, "Effect of illumination intensity on solar cells parameters," Energy Procedia, vol. 36, pp. 722-729, 2013.

[6] L. Musanga, W. Barasa, and M. Maxwell, "The Effect of Irradiance and Temperature on the Performance of Monocrystalline Silicon Solar Module in Kakamega," Physical Science International Journal, vol. 19, no. 4, pp. 1-9, 2018.

[7] U. Mandadapu, S. Edanayakam, and K. Thyagarajan, "Effect of Temperature and Irradiance on the Electrical Performance of a PV Module," International Journal of Advanced Research, vol. 5, no. 7, pp. 2018-2027, 2017.

[8] M. Bashir, H. Ali, S. Khalil, M. Ali, and A. Siddiqui, "Comparison of performance measurements of photovoltaic modules during winter months in Taxila," Pakistan, International Journal of Photoenergy, pp. 1-8, 2014.

[9] O. Rosyid, "Comparative performance testing of photovoltaic modules in tropical climates of indonesia," in AIP Conference Proceeding, 2nd PADJADJARAN International Physics Symposium, 2016.

[10] R. Nasrin, M. Hasanuzzaman, and N. Rahim, "Effect of high irradiation on photovoltaic power and energy," International Journal of Energy Research, vol. 42, no. 3, pp. 1115-1131, 2018.

[11] A. Zdyb and S. Gulkowski, "Performance Assessment of Four Different Photovoltaic Technologies in Poland," Energies, vol. 13, no. 1, p. 196, 2020.

[12] D. Cotfas and P. Cotfas, "Comparative Study of Two Commercial Photovoltaic Panels under Natural Sunlight Conditions," International journal of photoenergy, 2019.

[13] K. A., A. Gebremedhin, and N. Ibrahimi, "A comparison of the performance of mono-Si and poly-Si photovoltaic modules operating under Kosovo climate condition," Journal of Renewable and Sustainable Energy, vol. 10, no. 1, 2018.

[14] E. Karami, M. Rafi, A. Haibaoui, A. Ridah, B. Hartiti, and P. Thevenin, "Performance analysis andcomparison of different photovoltaic modules technologies under different climatic conditions in Casablanca,"Journal of Fundamentals of Renewable Energy and Applications, vol. 7, no. 3, pp. 1-6, 2017.

[15] M. Aburiya and M. M.M., "The Effects of Solar Irradiance and Ambient Temperature on solar PV module output in Northern Ghana," Ghana Journal of Development Studies, vol. 4, no. 2, pp. 117-125, 2008.

[16] V. Weizer, H. Brandhorst, J. Broder, R. Hart, and J. Lamneck, "Photon-degradation effects in terrestrial silicon solar cells," J. Appl. Phys., vol. 50, no. 6, p. 4443, 1979.

[17] S. Dubois, N. Enjalbert, and J. Garandet, "Slow-down of the light-induced degradation in compensated solar grade multicrystalline silicon," Applied Physics Letters, vol. 93, p. 103510, 2008.

[18] O. Rosyid, "Comparative performance testing of photovoltaic modules in tropical climates of indonesia," in 2nd Padjadjaran International Physics Symposium 2015 (PIPS-2015), AIP Conf. Proc. 1712, 0200041-020004-8, 2015

[19] N. Kumar and M. Malvoni, "A preliminary study of the degradation of large-scale c-Si potovoltaic system under four years of operation in semi-arid climates," Results in Physics, vol. 12, pp. 1395-1397, 2019.

[20] D. Tobnaghi and D. Naderi, "The effect of solar radiation and temperature on solar cells performance," $E x$ tensive Journal of Applied Sciences, vol. 3, pp. 39-43, 2015.

[21] P. Arjyadhara, M. AS, and J. Chitralekha, "Analysis of solar PV cell performance with changing irradiance and temperature," International Journal of Engineering and Computer Science, vol. 2, pp. 214-220, 2013

[22] C. Ferrari and D. Phillip, "Why do PV modules fail," Energy Procedia, vol. 15, pp. 379-386, 2012.

[23] R. L. Crabb, "Photon induced degradation of electron irradiated silicon solar cells," in Proceedings of the 9th IEEE Photovoltaic Specialists Conference. Silver Springs, MD, USA: IEEE, 1972, pp. 243--249.

[24] J. Schmidt, A. Aberle, and R. Hezel, "Investigation of carrier lifetime instabilities in $\mathrm{Cz}$-grown silicon," in Proceedings of the 26th IEEE Photovoltaic Specialist Conference, Anaheim, CA, USA, 1997, pp. 13-18.

[25] "The study of effect of light induced degradation on monocrystalline and polycrystalline photovoltaic modules," College of Engineering, Kwame Nkrumah University of Science and Technology, Kumasi, Ghana, 2020, BSc Project Report. 